\title{
Invasive alien plants and Eupatorium: Biodiversity and livelihood
}

\author{
Ripu M Kunwar* \\ Society for Economicand Environmental Development (SEED), Kathmandu, Nepal \\ *For correspondence, E-mail:ripu@wlink.com.np
}

\begin{abstract}
Invasive alien species colonize aggressively, threatening native biodiversity. The success of invasive alien plants is due to their opportunistic exploitation of anthropogenic disturbances, the absence of natural enemies, and, frequently, their allelopathic competitive strategies. Invasive species can have a significant impact on development, affecting sustainability of livelihood, food security and essential ecosystem services and dynamics. Eupatorium adenophorum Spreng. and E. odoratum L. (forest killer, local name banmara) are unpalatable and highly competitive. They have taken hold in scattered sites throughout eastern and central Nepal, currently, they are also rapidly spreading westward. Efforts are being made to control established invasive species, but a better understanding of why species become invasive offers the possibility of taking pre-emptive measures.
\end{abstract}

Key words: Invasive alien plant species, Eupatorium, biological control, livelihood

Him J Sci 1(2): 129-133

URL: www.himjsci.com/issue2/alienspecies

Received: 6 Apr 2003

Accepted after revision: 27 July 2003

\section{Introduction}

All of the threats to Nepal's biodiversity are due to the activities of human beings: habitat destruction and over-exploitation are accompanied by introduction of exotic species leading to habitat changeand soil degradation (Chaudhary 1998). Thewide range of habitats and environmental conditions makes Nepal especially vulnerableto theestablishment of invasivespecies of foreign origin. Potential invasive alien species from most areas of the world may find suitable habitat somewhere in Nepal. In recent years invasive species have gained considerable notoriety as major threats to nativespecies and ecosystem.

Introduction of plants from one placeto another may be natural or planned. Accidental and intentional introduction by gardeners, traders and foresters have contributed to the large number of exotic plants in Nepal. Nepal has a long history of introduction of non-nativespecies, especially species proven to be productive elsewhere and offering potential economic benefits to the country. Tamarindusindica (tamarind), originally from Africa, is believed to havebeen first introduced into Turkey in 126B.C.-220 A.D. (Yan et al. 2001), spreading gradually toward China along the 'Silk Road'; by now it has been thoroughly naturalized in Nepal. In the 19th century, the British were major contributors, bringing economicallyimportant plants fromalmost every continent (Islam 1991). Some of thealien treespecies, such as Tectona grandis(teak) and Albizia spp. (siris), were introduced for their timber potential or for watershed protection. Some now-common fruit trees, including Litchi chinensis (litchi), Ananas comosus (pineapple), and Cocosnucifera (coconut), were also introduced, as were most of thepulsesand oil yielding plants (Das 1982). Similarly, vegetables such as Cucurbita spp. (cucurbits), Raphnus sativus (radish), Solanum tuberosum (potato) and Daucus carota (carrot), came from other countries and havebeen welcomed by Nepalesefarmers. Likewise, Eupatorium odoratum, E. adenophorum, Lantana camara and Eichhornia crassipes were first introduced as ornamental plantsand they arenow well established and dominant in forest, farmland, wetland and wasteland.

In the20th century, thecountry'seconomic development including growth in trade and transportation systems multiplied the avenues of introduction and spread of invasive species. Newcomers such as Leucaena leucocephala (ipil ipil), Eucalyptus camaldulensis (masala), Acacia auriculoformis (watal), Cassia occidental is (chakor) and Samania saman, are becoming plantation favorites. In the hills and even in the Terai, fields are sown with the woody legume species L. leucocephala in order to rehabilitate soils left bare by intensive deforestation. In recent decades, however, there has been a growing awareness of the significant impact of such transformations of indigenous ecosystems.

Biological invasion worldwide threatens biodiversity, ecosystem dynamics, resource availability, national economy and human health (Ricciardi et al. 2000). It is a pervasive and costly environmental problem (Larson et al. 2001). Over the past half century it has become the focus of intense management and research activities worldwide(Kennedyetal. 2002). TheConvention on Biological Diversity (CBD), to which Nepal and 177 other countries are party, calls on governments to prevent the introduction, control or eradication of those alien species that threaten ecosystems, habitats or species (Article 8). However, approaches taken to combat this phenomenon and even the data on which they should be based are clearly inadequate to deal with theonslaughtof invasivespecies in Nepal. Participatory biodiversity conservation programme and an inventory of alien species are being run by International Union for Nature Conservation Nepal (IUCN/Nepal). However, accurate predictions of community susceptibility to invasion remain elusive. No story of theecosystem of Nepal will be complete or comprehensive without taking into account theroleplayed by the well-established Eupatorium species (local namebanmara, or "forestkiller"). Thisstudy isan attempt to 


\section{ARTICLES}

BOX 1. Recommended terminology in plant invasion ecology

\begin{tabular}{|c|c|}
\hline Nativeplants & $\begin{array}{l}\text { Plant species or subspecies or lower taxa, occurring within their natural range (past or present) and dispersal } \\
\text { potential (i.e. within therangethey occupy naturally or could occupy without direct or indirect introduction by } \\
\text { humans) }\end{array}$ \\
\hline Alien plants & $\begin{array}{l}\text { Plant taxa in a given area whose presencethere is dueto intentional or accidental introduction as a result of } \\
\text { human activity (Syn.: exotic plants, non-native, non-indigenous plants) }\end{array}$ \\
\hline Casual alien plants & $\begin{array}{l}\text { Alien plants that may flourish and even reproduce occasionallyin an area, but which do not form self-replacing } \\
\text { populations and which rely on repeated introduction for their persistence }\end{array}$ \\
\hline Naturalized plants & $\begin{array}{l}\text { Alien plants that reproduce consistently (casual alien plants) and sustain populations over many life cycles } \\
\text { without direct intervention by humans. They often recruit offspring freely, usually closeto adult plants, and do } \\
\text { not necessarily invadenatural or human-madeecosystems }\end{array}$ \\
\hline Invasiveplants & $\begin{array}{l}\text { Naturalized plants that produce reproductive offspring, often in very largenumbers, at considerable distances } \\
\text { from parent plants (approximatescales: }>100 \mathrm{~m} ;<50 \text { years for taxa spreading by seeds and other propagules; }>6 \\
\text { m/ 3yearsfor taxa spreading by roots, rhizomes, stolons, or creeping stems), and thus have the potential to } \\
\text { spread over a considerablearea }\end{array}$ \\
\hline $\begin{array}{l}\text { Invasivealien } \\
\text { plants }\end{array}$ & $\begin{array}{l}\text { Plants becomeestablished in natural or seminatural ecosystems or habitats and are agents of change, } \\
\text { threatening native biological diversity }\end{array}$ \\
\hline Weeds & $\begin{array}{l}\text { Plants (not necessarily alien) that grow in sites wherethey are not wanted and which usual ly have detectable } \\
\text { economic or environmental effects. Environmental weeds arealien plant taxa that invade natural vegetation, } \\
\text { usually adversely affecting native biodiversity }\end{array}$ \\
\hline
\end{tabular}

Sources: De Candolle (1855), Humphries et al. (1991), Randall (1997), Richardson (1998), IUCN/SSC (2000), Richardson et al. (2000)

review availableinformation on invasivespeciesand to recommend solutions.

\section{Invasive species}

The term 'invasive species' denotes plants and animals that: (i) have been introduced into ecosystems where they are not native by either intentional or unintentional human activity, (ii) have established self-reproducing populations, and (iii) have caused significant changes in pre-existing natural or artificial ecosystems (Richardson 1998) (Box 1).

Eupatorium specieshavearemarkablerange of altitudinal distribution (800 to 2000 m asl) in Nepal (Sharma and KC 1977), which overlaps with human settlements (Shrestha 1989). It has been sporadically spreading and now it is reported from 305 to $2500 \mathrm{~m}$ in abandoned slopesafter slash and burn cultivation (Joshi 1983), fallow lands and disturbed forests with severe human interference. It is represented by six species in Nepal (Press et al. 2000) viz. E. acuminatum, E. adenophorum, E. cannabinum, E. capillifolium, E. chinense and $E$. odoratum out of which two (E. adenophorum and $\mathrm{E}$. odoratum) are highly undesirable (Singh 1979). E. odoratumand E. adenophorum areaggressively colonizing abandoned slopes in the tropical to lower temperate zones, respectively (NBLP 2001). E. adenophorum wasintroduced in India after 1498 (Biswas 1934) and it is likely that it was introduced into Nepal from India through eastern border (Banerji 1958) probably before 1950. It is now widespread in eastern and central part of Nepal.

\footnotetext{
Mode of invasion

Biological invasion is a natural process. Nevertheless, the growing human population and improved worldwidetransport haveled to askyrocketing incidenceand scaleof invasions by non-indigenous species (Ewel et al. 1999). Their introduction relieson mutualism in their new habitats to overcome barriers to establishment and naturalization (Richardson et al. 2000). Parasitism is significantly reduced in organismsin theintroduced range, a fact that supports the 'enemy release hypothesis' (ERH) - the idea that species are morelikely to becomeinvasivewhen theyare released from control by their natural enemies (Torchin et al. 2003). The biotic resistance hypothesis (BRH) argues that diverse communities are highly
}

competitive and readily resist invasion because interactions with native species, including natural enemies, limit invaders' impacts (Darwin 1859, Maron and Vila 2001). Asa result, deep forest, which is less diverse than the forest margin, is vulnerable to ecological invasion (Pimm 1984). Distribution of invasive plants directly correlates with human disturbances, which can be easily seen in forest fringe areas. In general, increasing the frequency, intensity, spatial patterns, or scale of disturbances will likely lead to faster replacement of native species by exotic species (Yan et al. 2001). Massive invasion and spread is also typicallyallelopathic (Rai and Tripathi 1982, Chettri 1986).

Intentional introduction has been performed by various institutionsfor economic development, recreation uses, ecosystem betterment, highway beautification and creation of wildlifehabitat. It mayalso takeplace dueto import withoutquarantineof biological inputs, seeds and saplings, implements and fertilizersfrom foreign countries. Plants introduced for commercial and ecological purposes include Eucalyptus species, Grevillea robusta and Leucaena leucocephala. Someof themost invasiveand widespread unintentional introductions include the Amaranthus spp. (amaranth), Solidago spp. (gold enrod), Eupatorium spp. (crofton weed), Lantana camara, and Cestrum spp. (Table 1).

\section{Impacts: boon or bane?}

Introductions of non-native species can beboth boon and baneto society. The relative magnitudes of costs and benefits vary both in spaceand over time. Although an introduction maymeeta desired objective in one area, at one time, or for some sectors, unwanted and unplanned effects may also occur.

\section{Socio-economic impacts}

Humans depend heavily on non-native species for food, shelter, medicine, ecosystem services, aesthetic enjoyment and cultural identity. Intentionally introduced plants have priority over native species with respect to household economyand national economy. Onlyninecrops (wheat, maize, rice, potato, barley, cassava, soybean, sugarcane, and oats) which are cultivated far beyond their natural range yield over $70 \%$ of the world's food (Sattaur 1989). Similarly, 85\% of our industrial forestry plantationsareestablished with species of just three genera (Eucalyptus, Pinus and Tectona), which are 
TABLE 1. Some alien species, which have detrimental impacts on ecosystems

\begin{tabular}{|c|c|c|}
\hline Scientific Name & Origin & Impacton theecosystem \\
\hline Ageratum conyzoides(Asteraceae) & Mexico & Weed frequently encountered on cultivated land and wasteland \\
\hline Amaranthusspp. (Asteraceae) & N.America & Invasive, widely distributed weeds \\
\hline Cassia occidentalis(Fabaceae) & Trop. America & $\begin{array}{l}\text { Common weed of hillyareas; prevents the regeneration of } \\
\text { nativespecies }\end{array}$ \\
\hline Cestrum diurnum (Solanaceae) & Trop. America & Weed of roadsideand wasteland \\
\hline Chenopodium ambrosioides(Chenopodiaceae) & Trop. America & Weed of roadside \\
\hline Convolvulusarvensis(Convolvulaceae) & Europe & Common weed of wasteland and fallow land \\
\hline Conyza spp. (Asteraceae) & N. America & Common weed of farmlands and wastelands \\
\hline Eichhornia crassipes(Pontederiaceae) & S. America & $\begin{array}{l}\text { Probably the world's most widespread and serious invasive } \\
\text { aquatic weed }\end{array}$ \\
\hline Eucalyptuscamaldulensis(Myrtaceae) & Australia & Controversy over water recharge and discharge \\
\hline Eupatorium adenophorum (Asteraceae) & West Indies & $\begin{array}{l}\text { Common weed of wasteland; suppressed the regeneration of } \\
\text { other species }\end{array}$ \\
\hline Eupatorium odoratum (Asteraceae) & $\begin{array}{l}\text { Jamaica and } \\
\text { Mexico }\end{array}$ & $\begin{array}{l}\text { Common weed of wasteland; suppressed the regeneration of } \\
\text { other species }\end{array}$ \\
\hline Grevillea robusta (Proteaceae) & Australia & Agricultural landscapeand roadsideinvasion \\
\hline Ipomoea carnea (Convolvulaceae) & America & Common weed in aquatic and marshy habitat \\
\hline Lantana camara (Verbenaceae) & Trop. America & Common weed of wastelands \\
\hline Leucaena leucocephala (Fabaceae) & Trop. America & Suppress the regeneration of other species \\
\hline Ludwigia adscendendens(Onagraceae) & C. America & Common weed of all habitats \\
\hline Mimosa pudica (Fabaceae) & S. America & Common weed of cultivated and wasteland \\
\hline Opuntiastricta (Cactaceae) & $\begin{array}{l}\text { Caribbean } \\
\text { Coastal area }\end{array}$ & Widespread weed in hot and dryareas \\
\hline Plantago spp. (Plantaginaceae) & N. America & Common in grassland and along roadside \\
\hline Solidago sp. (Asteraceae) & N. America & Common in suburbs, along roadside \\
\hline
\end{tabular}

Sources: DeBach (1964), Das (1982), Islam (1991), Richardson (1998), Hossain and Pasha (2001)

also cultivated asexotics(Evans 1992). Thus, although nativespecies fulfill some human requirements, non-native species play an integral role in the economies and culture of most countries.

Despite the many benefits provided by alien species, deliberate and accidental introduction of these species poses a threat to native biodiversity and rural livelihoods. Theimpact may be devastating, and may entail reduction of carrying capacity of ecosystem (Banerji 1958), alterations in structure and function of natural ecosystem, human health hazards (Ricciardi et al. 2000), crop failure, species extinction, and reduced water yield from watersheds (Harrington andWingfield 1998). The distribution and composition of biodiversity and local forest resources is affected directly by the invasive species due to change in host pathogen relationship and species competition. Theinvadersthereby affect the availability of forest resources, both timber and non-timber forest products. This may cause a change in the local people's utilization patterns of forest resources.

Invasion of Eupatorium is an enormous problem. Transitional zones and swamp forest are being invaded by dense monospecific standsof Eupatorium, which havelittleunderstorey except for Eupatorium seedlings. Although the species of Eupatorium have pesticidal properties (Chettri 1986) which have been applied in a few areas of Nepal, no commercially viable application has been found. Neither cattlenor goats eat this plant, and areas traditionally used for grazing can no longer be used for this purpose, forcing villagers to walk farther in search of grazing pasturage. Theincreased timespent on this activity translates into a substantial economic loss. The alternative, trying to control the weed, also involves a burden of labour and financial investment.
Eupatorium spp. growing in fallow land prevents soil erosion. They are used as green manure during spring, when the plant is heavily laden with leaves. Dried Eupatorium may be burnt to yield potash rich fertilizer. In some parts of the country, it has been used for cattlebedding material (Shrestha 1989). Eupatorium leaves when boiled and taken, cure severe stomachache and the apical leaves when madeinto pasteand slaked with limeand applied on the cuts, stops bleeding (Joseph and Kharkongor 1981). Local people apply the fresh juice of Eupatorium leaves to stop bleeding from cuts and wounds (NBLP 2001).

\section{Ecological impact}

The dominance of Eupatorium specieshasoccurred in transitional zones with adequate moisture (Kunwar 2000) and disturbance regimes, which can be easily seen in disturbed forest sites (Baniya and Bhattarai 1984). This plant inhibits growth and may even kill local plants and domestic animals (Jha and Sah 1985). Although many factorsinteractto determinethesusceptibilityofan ecosystem to invasion by Eupatorium, habitats may be ranked according to their vulnerability: undisturbed forest $<$ moderately disturbed forest $<$ disturbed forest < shrub land < grassland < dunes < denuded land (Richardson and Higgins 1998). Roads or trails, which usually occur in transition areas, often function asconduitsfor thedispersal of alien plants (Hobbsand Mooney 1991).

Invasivealien species(Ageratum conyzoides, Eupatorium spp., Imperata cylindrica etc.) grow luxuriantly in sunny exposed wasteland (Kunwar et al. 2001) and encroach fresh landslides or areas with deep gullies and open grasslands. The invasive species spread primarily through wind dispersal and propagate through 
vegetativemeans (Saxena and Ramakrishnan 1984). Theonceslow, erratic and small-scaletransfer of specieshas shifted to a rapid and large-scale translocation; the rate of invasions in San Francisco Bay, for instance, has accelerated from an average of one new species established every 55 weeks during the period 1851-1960 to onenewspeciesevery 14 weeksduringtheperiod 1961-1995(Cohen and Carlton 1998). Thus, theinvasiveeffectsof thesespecies become compounded because of their growth mode and the reproductive strategy. They can promote fire and alter water and nutrient availability. Moreover, thecattlegrazing and trampling hasallowed noxious Eupatorium spp. to take root (NEPA 1998).

It isargued that the complexityof theinteractions between alien plants, the native biota and the environment they invade precludes prediction (Brukeand Grime1996). Invasivealien species reduce biodiversity, replace economically important native plant species and increasetheinvestment in agricultureand silviculture (Ricciardi et al. 2000), disrupt prevailing vegetation dynamics and alter nutrientcycling(Richardson 1998). Theinvasion processaffects all ecosystems but the impact of particularly aggressive species is especially severe on the structure and function of vulnerable and isolated ecosystems (SCBD 2001). In native forests, invasive alien plants are able to dominate the understorey, to strangle saplings and to suppress native species (Denslow 2002). The problem will likely worsen with time because of climatic changes that promote species migration worldwide.

Invasive plants also have a major impact on catchment hydrology: 30-70\% lower water runoff is reported from watershed areas with dense stands of alien species (Geldenhuys 1986). M ost impacts are detrimental to the invaded systems and threaten sustained functioning and the provision of important ecosystem services. The reduced stream flow obviously has detrimental impactson aquatic biota. It can also disruptstock watering, irrigation, tourism and recreational use of resources and heritages.

\section{Controlling measures}

The spread of invasive alien species is creating complex and farreachingchallengesthat threaten both the natural biological niches of the earth and the well-being of its citizens. Some aspects of the problem require solutions addressing the specific values, needs, and priorities of local ecosystems, national environment and sustainabledevelopment. It isnow widely accepted that thecontrol of invasive alien species is not a short-term or single effort. On the contrary, it requires detailed surveillance, monitoring and research into the most suitable long-term control options. Much effort is devoted to controlling them after they areestablished, but a better understanding of whyspecies becomeinvasiveoffers thepossibility of taking pre-emptive measures (Clay 2003).

A variety of well-known methods can be used as measures to control alien invasive species and their spread. These vary from administrative (national and international cooperation and coordination, database management, legislation regarding quarantine and so on), to mechanical (including digging up root systems, slashing and chopping), to chemical (utilizing acceptable and tested herbicides) and to biological (makinguseof plantspecific insectsor pathogens to damageand control aliens). Theseoptions are generally incorporated into integrated control programme employing a combination of strategies which together may impede and control the invasive species to some extent.

Suitablestrategies are needed to conserve the forest and its biodiversity while ensuring a sustainable resources base for indigenouspeople. Biological control ofEupatoriumspeciesusing gall fly Procedidocharesutilishas been carried out throughout world including Nepal. It was successful in Hawaii, USA, and elsewhere (Bess and Haramota 1971); however, this technique has not yet been successful in Nepal. 'Best management practices' should include removal of known invasives, and their use should be discouraged. Known invasive alien plant should be replaced with non-invasive native species or with exotics unlikely to spread into native plant communities. Horticultural material such asseed and green mulch should be inspected for their potential to introduce troublesomespecies. Nurseries, botanical gardensand government agencies should inform the public of the potential danger of invasive speciesand should encouragetheuse of alternativenativeor exotic species unlikely to contribute future invasive species problem.

Somestrategiesthaturgently requireimplementation are: (i) alert local peopleto theimportanceand impacts of alien species; (ii) accord highest priority to preventative initiatives designed to protect vulnerable ecosystems; (iii) give priority to the eradication of invasive alien species on areas that with highly distinctive ecosystems and threatened and endemic species; (iv) undertakea systematic compilation of research and educational materials and initiate a database on invasive species; (v) conduct more research; (vi) introducelegislation regardingquarantines; and (vii) strengthen international cooperation, national coordination, and local implementation of policiesconcerningalien species.

\section{Conclusion}

The deliberate introduction of alien invasive species threatens to nativespecies, habitatsand ecosystem functionsand iseconomically costly. The major impact of alien invasion follows reduction in forest product availability, which directly affects the rural livelihood because the subsistence of rural livelihood entirely relies on such products. Thus, some aspect of the problem requires solutions addressing the specific needs and priorities of human livelihood, local ecosystems and national environment and sustainable development. Concurrently, it ismoreessential to understand why these species becomeinvasive.

\section{References}

Banerji NL. 1958. Invasion of Eupatorium glandulosum in east Nepal. Bulletin of botanical society, University of Saugar 10(1 and 2): 14-8

Baniya AMSand MD Bhattarai. 1984. Distribution of Eupatorium adenophorum in somepartsof Phulchoki hillsand itssoil relation. Kathmandu: Amrit Campus. $38 \mathrm{p}$

Bess HA and FH Haramota. 1971. Biological control of Pamakani Eupatorium adenophorum in Hawaii by a tephritid gall fly, P. utilis. Proc Hawaii Entomol Soc 21(2): 165-78

BiswasK. 1934. Distribution of someof thecommon harmful exotic weedsestablished in the country. Ind For 60: $861-5$

BrukeMJW and J Grime. 1996. An experimental study of plantcommunityinvisibility. Ecology 77: 776-90

Clay K. 2003. Parasites lost. Nature 421: 585-6

Cohen AN and JT Carlton. 1998. Accelerating invasion rate in a highly invaded Estuary. Science279: 555-8

Chaudhary RP. 1998. Biodiversityin Nepal: Statusand conservation. MajupuriaTC (ed). Bangkok: Tecpress Books. $324 \mathrm{p}$

Chettri MK. 1986. Effects of herbicides on Eupatorium adenophorum [thesis]. Kathmandu: Central Department of Botany, Tribhuvan University. $61 \mathrm{p}$

Darwin C. 1859. On theorigin of speciesbymeans of natural selection. London:John Murray. $448 p$

Das S. 1982. Introduction of exotics in the plantation forestry of B'desh. In: Proceedings of Second B'desh National Conference on Forestry; Dhaka. p 85-93

De Bach P. 1964. Projects on biological control of insect pests and weeds. London: Chapman and Hall. xxivp

DeCandolleAP. 1855. Geographic botaniqueraisonne, Vol 2. Paris:V Masson

DenslowJS. 2002. Invasivealien woody species in Pacific Island forests. Unasylva 209: $62-3$

Evans]. 1992. Plantation forestryin thetropics, 2nd ed. Oxford: Clarendon press

Ewel JJ, DJ O'Dowd, J Bergelsen, CC Daehler, CM D'Antonio, LD Gomez et al. 1999. Deliberateintroductions of species: Research needs. Bioscience 49: 619-30

Geldenhuys CJ. 1986. Costs and benefits of the Australian Blackwood Acacia melanoxylon in South African forestry. In: Macdonald IAW, FJ Kruger and AA Ferrar (eds), Theecologyand management of biological invasionsin southern Africa. CapeTown: Oxford University Press. p 275-84

Press JR, KK Shrestha and DA Sutton. 2000. Annotated checklist of the flowering plants of Nepal. London:TheNatural History Museum, London and Tribhuvan University, Kathmandu. 430p

Harrington TC and MJ Wingfield. 1998. Diseases and the ecology of indigenous and exotic pines. In: Richardson DM (ed), Ecologyand biogeography of Pinus. 
Cambridge: CambridgeUniversity Press. p 381-404

HobbsRJ and HAMooney. 1991. Effects of rainfall variability on gopher disturbance on serpentine annual grassland dynamics in north California. Ecology $\mathbf{7 2}$ 59-68

Hossain MK and MK Pasha. 2001. Alien invasive plants in B'desh and their impacts on the ecosystem. Alien 13: 12-3

Humphries SE, RH Groves and DS Mitchell. 1991. Plant invasions of Australian ecosystems. Kowari 2: 1-134

Islam AKMN. 1991. Two centuries of plant studies in B'desh and adjacent regions. Asiatic Society of B'desh. Dhaka

IUCN/SSC. 2000. Guidelinesfor theprevention of biological diversity: Losscaused byalien invasi vespecies. Gland (Switzerland): Species Survival Commission (SSC), International Union for Nature Conservation, Invasive Species Specialist Group

Jha PK and RP Sah. 1985. Banmara (Eupatorium adenophorum): Nepal'sworst weed. Kathmandu: $M$ an and Biosphere. Bulletin no 5

JosephJ and P Kharkongor. 1981. A preliminary ethnobotanical survey in theKhari and Jaintic hills, Meghalaya. In:Jain SK (ed), Glimpseof Indian ethnobotany. New Delhi: Oxford and IBH Publishing Co. p 115-23

Joshi RM. 1983. Role of soil, light and water in the distribution of Eupatorium adenophorum in Phulchoki hillsof Kathmandu [thesis]. Kathmandu: Central Department of Botany, Tribhuvan University. $52 p$

KennedyTA, N Shahid, MH Katherine, MHKJokannes, T David and R Peter. 2002 Biodiversity as a barrier to ecological invasion. Nature 417: 636-8

Kunwar RM, VNG Gupta, OR Vetaas and RP Chaudhary. 2001. Vegetation dynamics of herbaceous plants in lower Arun river basin of Makalu Barun buffer zone east Nepal. In: Watanabe T, S Sicroff, NR Khanal and MP Gautam (eds), Proceeding of theinternational symposium on theHimalayan environments: Mountain sciencesand ecotourism/biodiversity; 2000Nov24-26; Kathmandu. Kathmandu: Hokkaido University, Tribhuvan University and the United Nations University. p 103-10

Kunwar RM . 2000. Species diversity of herbaceousflora in lower Arun river basin Makalu Barun buffer zone, east Nepal [thesis]. Kathmandu: Central Department of Botany, Tribhuvan University. $45 p$

Larson DL, PJ Anderson and W Newton. 2001. Alien invasion in mixed-grass prairie: Effects of vegetation type and anthropogenic disturbance. Ecol Appl $\mathbf{1 1}$ 128-41

Maron JL and M Vila. 2001. When do herbivores affect plant invasion? Evidencefor the natural enemies and biotic resistance hypothesis. OIKOS 95: 361-73

NBLP. 2001. Makalu Barun landscapeproject; Biodiversitycomponent. Kathmandu Nepal Biodiversity Landscape Project, DNPWC, HMGN. Report no $1.87 \mathrm{p}$

NEPA. 1998. Biodiversity country report. Beijing: National Environment Protection
Agency

Pimm SL. 1984. The complexity and stability of ecosystem. Nature307: 321-6

Rai JPN and RSTripathi. 1982. Allelopathy as a factor contributing to dominance of Eupatorium. Ind J Ecol 9: 14-20

Randall JM. 1997. Defining weeds of natural areas. In: Luken JO and JW Thieret (eds), Assessment and management of plant invasions. New York: SpringerVerlag. p 18-25

Ricciardi A, WWM Steiner, RN Mack and D Simerloff. 2000. Towards a global information system for invasive species. Bioscience 50(3): 239-44

Richardson DM and SI Higgins. 1998. Pines asinvasion in thesouthern hemisphere In: Richardson DM (ed), Ecology and biogeography of Pinus. Cambridge: Cambridge University Press. p 450-73

Richardson DM, P Pysek, M Rejmanek, M G Barbour, FD Panetta and CJ West. 2000. Naturalization and invasion of alien plants: Concepts and definitions. Diver Distribution 6: 93-107

Richardson DM. 1998. Forestry trees as invasive aliens. Conserv Biol 12: 18-26

Sattaur O. 1989. The shrinking gene pool. New Sci 1675: 37-41

SaxenaKG and PSRamakrishnan. 1984. Growth and patterns of resourcesallocation in Eupatorium odoratum in secondary successional environment following slash and burn agriculture. Weed Res 24: 127-34

SCBD. 2001. Review of the efficiency and efficacy of existing legal instruments applicable to invasive alien species [Technical series no 2]. Montreal: Secretariat of the convention on biological diversity, CBD. $42 \mathrm{p}$

Sharma KC and GK KC. 1977. Reports on studies on the biological controls of Eupatorium adenophorum in Nepal. J Agric 12: 135-58

Shrestha TB. 1989. Development of theArun river basin, Nepal: Countryreport on biological diversity. Kathmandu:ICIMOD. 133p

Singh RM. 1979. The autoecology of Eupatorium adenophorum: A noxious weed [thesis]. Kathmandu: Central Department of Botany, Tribhuvan University. $54 \mathrm{p}$

Torchin ME, KD Lafferty, AP Dobson, VJ Mckenzieand AM Kuris. 2003. Introduced species and their missing parasites. Nature 421: 628-30

Yan X, L Zhenyu, WP Gregg and L Dianmo. 2001. Invasive species in China: An overview. Biod Conserv 10: 1317-41

\section{Acknowledgements}

Thanks are due to Sagendra Tiwari, IUCN and Ram P Chaudhary, Central Department of Botany, Tribhuvan University, for their valuable suggestions, and toVijaya Kunwar, Society for Economic and Environmental Development (SEED), Nepal for providing necessary supports. 